Reeks 'Individuele ontwikkeling en employability in organisaties'

\title{
Employability en individuele ontwikkeling op het werk
}

\author{
Karen van Dam, Beatrice I.J.M. van der Heijden, Birgit Schyns*
}

De aandacht voor de employability en individuele ontwikkeling van medewerkers is de laatste decennia behoorlijk toegenomen. Door veranderingen binnen en buiten organisaties is een behoefte aan flexibele organisaties met breed inzetbaar personeel ontstaan en zijn werknemers zelf verantwoordelijk geworden voor de eigen loopbaanontwikkeling en werkzekerheid. Dit artikel gaat in op recente veranderingen op het werk die de achtergrond vormen van de nadruk op leren en inzetbaarheid. Daarna wordt aandacht besteed aan de begrippen employability en werkgerelateerd leren, aan factoren die verbonden zijn met individuele ontwikkeling op het werk en aan de invloed van leeftijd op ontwikkeling. Daarmee is dit artikel tevens de start van een nieuwe reeks in Gedrag $\&$ Organisatie: 'Individuele ontwikkeling en employability in organisaties'.

Trefwoorden: personeelsontwikkeling, employability, leergedrag, HRD

\section{Inleiding}

Door ingrijpende veranderingen binnen en buiten organisaties is het belang van de individuele ontwikkeling en employability van werknemers de laatste jaren toegenomen. Snelle technologische ontwikkelingen, internationale concurrentiedruk en verplatting van de organisatie zijn voorbeelden van ontwikkelingen die ervoor hebben gezorgd dat de competenties van medewerkers tot een cruciale factor voor de concurrentiepositie van organisaties zijn geworden. Om op ontwikkelingen in de omgeving te kunnen inspelen is het voor organisaties van belang dat medewerkers

\footnotetext{
* Karen van Dam, Universiteit van Tilburg. Correspondentieadres: Dr. K. van Dam, Universiteit van Tilburg, Arbeids- en Organisatiepsychologie, Postbus 90153, 5000 LE Tilburg. E-mail: k.vandam@uvt.nl.

Beatrice I.J.M. van der Heijden, Maastricht School of Management \& Open Universiteit Heerlen.

Birgit Schyns, Universiteit Twente.
} 
'up-to-date' en breed inzetbaar zijn. Maar de organisatie is natuurlijk niet de enige partij die hierbij is gebaat. Als gevolg van de afgenomen baanzekerheid zijn werknemers meer verantwoordelijk geworden voor de eigen loopbaanontwikkeling en de daaraan gerelateerde kansen op de arbeidsmarkt. Door de eigen competenties te ontwikkelen kunnen medewerkers hun inzetbaarheid op de interne én de externe arbeidsmarkt, ofwel hun employability, vergroten. Daarmee is de employability van medewerkers niet alleen gerelateerd aan de overlevingskansen van organisaties maar ook aan de arbeidsmarktpositie van individuele medewerkers. Juist deze laatste invulling is voor overheden aanleiding geweest om employability binnen een bredere maatschappelijke context te plaatsen (zie McQuaid \& Lindsay, 2005).

Door de voortdurende veranderingen in en rond organisaties en de nadruk op employability is ook de aandacht voor de individuele ontwikkeling van medewerkers de laatste jaren toegenomen. Daarbij wordt het ontwikkelen van medewerkers niet langer als een incidenteel gebeuren maar als een continu proces opgevat (McCauley \& Hezlett, 200I). Van werknemers wordt verwacht dat zij openstaan voor nieuwe ontwikkelingen en dat zij zich op toekomstige taken voorbereiden door het onderhouden en uitbreiden van de eigen competenties (London \& Mone, I999). Het is daarbij de vraag of incidentele trainingen en formele opleidingen voor deze continue ontwikkeling voldoende adequaat zijn. De laatste tijd is de aandacht in organisaties en onderzoek verschoven van het leren door middel van formele trainingsprogramma's naar het leren op het werk zelf. Juist die dagelijkse werksituatie biedt aanknopingspunten voor ontwikkelingsprocessen en het op peil houden van de kennis en kunde van medewerkers. Dit betekent dat medewerkers zich binnen en buiten de werksituatie kunnen ontwikkelen en daarmee hun employability kunnen bevorderen.

Om aan deze dynamiek van employability en individuele ontwikkeling op het werk aandacht te schenken zal Gedrag E Organisatie een reeks artikelen publiceren. Als opening van deze reeks wil de huidige bijdrage ingaan op recente veranderingen op het werk die de achtergrond vormen van de nadruk op leren en inzetbaarheid. Daarna wordt aandacht besteed aan de begrippen employability en werkgerelateerd leren, en aan factoren die verbonden zijn met het leren op de werkplek. In het laatste deel van ons overzicht laten we zien hoe leeftijdsontwikkelingen op de arbeidsmarkt employability en leren beïnvloeden. Met dit overzicht willen we een stimulans geven aan onderzoekers die binnen (en buiten) deze reeks in Gedrag $\mathcal{E}^{\circ}$ Organisatie bijdragen aan de kennis over employability en leren binnen moderne organisaties alsook aan organisaties die de individuele ontwikkeling en employability van hun medewerkers als prioriteit zien.

\section{Veranderingen in en rond organisaties}

Organisaties zijn in de afgelopen decennia sterk veranderd. Als gevolg van wereldwijde economische recessies zagen organisaties zich gedwongen hun structuur en strategie aan te passen. In een poging de kosten te drukken en aan efficiency te winnen, begonnen veel bedrijven te reorganiseren, nieuwe markten te zoeken en werk naar lagelonenlanden te verplaatsen. De concurrentiepositie van bedrijven is verder onder druk komen te liggen door de toegenomen klantgerichtheid, waarbij organisaties om 
klanten binnen te halen voortdurend nieuwe producten ontwikkelen en in de markt zetten, met als gevolg dat veel organisaties in een voortdurend veranderingsproces zijn terechtgekomen.

Om in deze snel veranderende wereld het hoofd boven water te houden zijn veel organisaties genoodzaakt hun aanpassingsvermogen en flexibiliteit te vergroten. Sinds de jaren tachtig zijn in de literatuur verschillende modellen en opvattingen over de flexibele organisatie gepresenteerd (zie Legge, I995; Glastra, Van der Haar, Lens \& Schedler, 2004). Veel van deze modellen leggen de nadruk op de structuur van de organisatie. In plaats van de traditionele, hiërarchische structuur, met grote aantallen werknemers die voltijds in vast dienstverband werken, kunnen organisaties beter gebruikmaken van flexible of organische structuren, met tijdelijke arbeidscontracten (Atkinson, I984), met mogelijkheden tot projectmanagement, decentralisatie en delegatie van beslissingen (Guest, 1987) en met laterale in plaats van verticale communicatielijnen (Burns \& Stalker, I966). Daarnaast kunnen organisaties hun flexibiliteit vergroten door te investeren in de ontwikkeling en brede inzetbaarheid van een selecte groep kernmedewerkers, die verantwoordelijk zijn voor de ontwikkeling en uitvoering van bedrijfsspecifieke activiteiten met een strategisch belang voor de organisatie (Atkinson, I984; Handy, I988).

De behoefte van organisaties om adequaat op veranderingen in te spelen heeft twee trends in gang gezet die belangrijke implicaties hebben voor de employability en ontwikkeling van werknemers. In de eerste plaats heeft de nadruk op flexibilisering een invloed gehad op de relaties tussen de organisatie en haar medewerkers en daarmee op de houding van medewerkers ten aanzien van de eigen loopbaan. Omdat werkgevers voorheen 'lifetime employment' aanboden, speelden loopbanen zich voornamelijk binnen dezelfde organisatie, of binnen een beperkt aantal organisaties, af. In deze 'bounded careers' ligt de verantwoordelijkheid voor die loopbaan grotendeels bij de organisatie (Fugate, Kinicki \& Ashforth, 2004). Omdat lifetime employment bij dezelfde werkgever niet langer gegarandeerd is, hebben werknemers naar andere manieren gezocht om hun werkzekerheid veilig te stellen (Forrier \& Sels, 2003). Naast de traditionele bounded career is tegenwoordig in toenemende mate sprake van de 'boundaryless career' (Arthur, 1994), die zich over verschillende organisaties, functies en zelfs professionele werkvelden uitstrekt. Hall (1976, 2002) spreekt in dit verband van de 'Protean career', naar de Griekse god Proteus die het vermogen bezat van vorm te veranderen. Kenmerkend voor de flexibele werknemer is dat deze over een groot aanpassingsvermogen beschikt, verschillende identiteiten en rollen kan hanteren en, vooral, dat deze proactief is (Fugate et al., 2004). Dat betekent dat de werknemer geen passieve aanpasser is, die reageert op de veranderingen die zich rond hem afspelen, maar dat deze zelf het initiatief neemt om veranderingen te bewerkstelligen (Crant, 2000; Frese \& Fay, 200I). Het vermogen om aan de vele veranderingen het hoofd te kunnen bieden is daarmee een belangrijke voorwaarde voor loopbaansucces geworden (Fugate et al., 2004; Pulakos, Arad, Donovan \& Plamondo, 2000). Door zich te oriënteren op de arbeidsmarkt, open te staan voor nieuwe ontwikkelingen en zich te blijven ontwikkelen, weet de moderne werknemer nieuwe arbeidsmarktkansen te genereren. 
In de tweede plaats hebben de snelle ontwikkelingen op de markten en de daarmee verbonden behoefte aan flexibel inzetbaar personeel implicaties gehad voor de opvattingen van organisaties over expertise en individuele ontwikkeling. Men realiseerde zich dat flexibiliteit en brede inzetbaarheid alleen kan worden bereikt als werknemers over kennis en vaardigheden beschikken die actueel zijn en breder dan voor de huidige functie nodig is. Om de personeelsontwikkeling te faciliteren hebben veel organisaties daarom de filosofie van continue ontwikkeling omarmd (Noe, Wilk, Mullen \& Wanek, 1997). Terwijl in het verleden de nadruk vooral lag op de ontwikkeling van managers en van managementpotentieel, betreft de filosofie van continue ontwikkeling de ontwikkeling van medewerkers op alle niveaus van de organisatie (Poell, Van Dam \& Van den Berg, 2004). Daarmee is voor veel organisaties en werknemers employability en 'life-long learning' het adagium geworden.

\section{Employability}

Hoewel de term employability vooral in de jaren negentig algemene bekendheid kreeg, was het begrip daarvoor al langere tijd in gebruik (Forrier \& Sels, 2003; Gazier, I998). Aanvankelijk had het begrip vooral betrekking op de loopbaankansen van specifieke groepen, zoals langdurig werkelozen of gehandicapten (Feintuch, I955). De nadruk lag daarbij op de economische en maatschappelijke noodzaak de inzetbaarheid van deze groepen te bevorderen, zodat zij aan het arbeidsproces zouden kunnen deelnemen. In de jaren tachtig werd employability in verband gebracht met de functionele flexibiliteit van het personeel. Zoals eerder opgemerkt waren organisaties als gevolg van economische en technologische factoren genoodzaakt hun efficiëntie en flexibiliteit te vergroten. Een flexibele inzet van medewerkers stelt organisaties beter in staat het aanbod van producten op de snelle veranderingen in de markt af te stemmen (Gaspersz \& Ott, I996; Thijssen, 2000). In de jaren negentig verschoof de nadruk en werd employability opnieuw gezien als arbeidsmarktinstrument, niet zo zeer voor specifieke groepen maar nu voor de gehele populatie (Forrier \& Sels, 2003). Door de opkomst van de boundaryless career was niet alleen de inzetbaarheid van de werknemer op de interne arbeidsmarkt maar tevens diens aantrekkelijkheid voor de externe arbeidsmarkt van belang.

Deze ontwikkeling maakt duidelijk dat het begrip employability op verschillende niveaus een verschillende betekenis kan hebben. Op het niveau van de individuele werknemer kan employability worden gezien als een proactieve respons op de snelle veranderingen die in en rond organisaties plaatsvinden, die tot doel heeft de interne en externe inzetbaarheid te vergroten door middel van de ontwikkeling van relevante competenties en expertise. Een goede inzetbaarheid zorgt niet alleen voor meer werkzekerheid, maar stelt werknemers tevens in staat een loopbaan te realiseren die het beste bij hen past. Op het niveau van de organisatie kan employability worden gezien als het vermogen en de bereidheid van werknemers taken te vervullen die breder zijn dan de huidige functie (Van Dam, 2004). Daarbij komt steeds meer aandacht voor de bijdragen van werknemers die buiten de formele taakstellingen plaatsvinden, zoals creativiteit en innovatief gedrag (Bettencourt, 2004). Op politiek en maatschappelijk niveau refereert employability aan het vermogen van het 
individu om werk te verkrijgen. Employability wordt dan vooral gebruikt in verband met de arbeidsmarktkansen van groepen met een zwakkere positie op de arbeidsmarkt, zoals laagopgeleide jongeren en allochtonen (zie McQuaid \& Lindsay, 2005). Dat employability wordt gekoppeld aan de ontwikkeling van relevante kwaliteiten en competenties onderschrijft de dynamiek van het begrip; in een snel veranderende wereld blijft een werknemer zonder ontwikkeling niet lang employable. Juist omdat employability zo dynamisch is, is het van belang dat werknemers een open, flexibele en proactieve houding hebben ten aanzien van de eigen inzetbaarheid. Van Dam (2004) spreekt in dit kader van de employability-oriëntatie van het individu, daarmee verwijzend naar de houding en activiteiten van werknemers ten aanzien van de eigen inzetbaarheid. Ook anderen wijzen op het belang van persoonlijke flexibiliteit (Van der Heijden, 2005) en aanpassingsvermogen (Ashford \& Taylor, I990; Chan, 2000; Fugate et al., 2004). Volgens Fugate et al. (2004) wordt het aanpassingsvermogen van de werknemer vooral bepaald door dispositionele kenmerken, zoals optimisme, openstaan voor veranderingen, het vermogen om te leren, interne 'locus of control' en een gevoel van 'self-efficacy'. Anderen wijzen daarnaast op de relevantie van buiten het individu liggende factoren, zoals de werkomgeving, een leerklimaat, en het HRM-beleid (Van der Heijden, 2005). Onderzoek van Van Dam $(2003,2004)$ heeft laten zien dat de employability-oriëntatie gerelateerd is aan zowel dispositionele kenmerken, zoals openstaan voor veranderingen, als omgevingsaspecten, zoals de steun van de leidinggevende ten aanzien van de loopbaan. Andere aspecten van de werksituatie zijn eveneens aan een flexibele opstelling van medewerkers gerelateerd, zoals afwisseling in het werk, sociale contacten, persoonlijke ontwikkelingsmogelijkheden en bewuste aandacht van de organisatie voor opleiding en training, loopbaanontwikkeling en personeelsplanning (Glasbergen, I994; Steenbakkers, 1996). Tot slot leggen sommigen een relatie met de arbeidsmarkt en de economische en sociale context waarbinnen naar werk wordt gezocht (Hillage $\&$ Pollard, I998). Kennis van de arbeidsmarkt (Kluytmans \& Ott, I999) en de afstemming tussen vereiste en beschikbare competenties (McQuaid, Green \& Danson, 2005) zijn enkele van de factoren die de employability van werkzoekenden kunnen beïnvloeden.

Het zal duidelijk zijn dat er verschillende invalshoeken zijn om naar het fenomeen employability te kijken en het begrip te definiëren. Gegeven deze situatie is het van belang dat employability-onderzoek allereerst gestoeld wordt op een gedegen conceptualisatie en operationalisatie (De Grip, Van Loo \& Sanders, 2004; Forrier \& Sels, 2003; Fugate et al., 2004; Harvey, 200I; Van der Heijden \& Thijssen, 2003). Dit is nog niet het geval. In de literatuur vinden we veelal brede conceptualisaties zonder een gedegen operationalisatie van het begrip. Als er al onderzoek is verricht, ligt de nadruk op uiteenlopende dimensies, zoals het waargenomen vermogen van het individu werk te vinden of te houden, de vaardigheden en kenmerken die nodig zijn voor een nieuwe baan, de activiteiten waarmee individuen hun employability kunnen vergroten, variërend van ontwikkelingsactiviteiten tot het zoeken naar werk, en de effecten van employability, zoals die bijvoorbeeld tot uitdrukking komen in de kwaliteit van een arbeidsmarktpositie (zie voor een overzicht Forrier \& Sels, 2003; McQuaid et al., 2005). Daarbij is er weinig eensgezindheid over de status van deze dimensies; gaat het om aspecten, indicatoren of antecedenten van employability? 
Kortom, het ontbreekt aan een overkoepelend theoretisch raamwerk om deze resultaten te integreren en aan een gedegen conceptualisatie en operationalisatie om de individuele employability te kunnen onderzoeken. Een heldere definitie en adequate operationalisatie van het begrip employability zal niet alleen het debat en de kennisontwikkeling over dit fenomeen ten goede komen (Forrier \& Sels, 2003), maar draagt ook bij aan een kritische analyse van de mogelijkheden om de blijvende inzetbaarheid gedurende de loopbaan te stimuleren.

\section{Individuele ontwikkeling op het werk}

Door de nadruk op employability en life-long learning is de individuele ontwikkeling van medewerkers bij steeds meer organisaties en onderzoekers op de agenda komen te staan. Aanvankelijk lag de nadruk op training, waarbij medewerkers buiten de dagelijkse werksituatie in een formele leersituatie onder begeleiding van een expert nieuwe vaardigheden en kennis kregen aangereikt. Onderzoek richtte zich in eerste instantie op het ontwerp en de effectiviteit van de training (Robinson \& Robinson, 1989), de transfer van het geleerde naar de werksituatie (Baldwin \& Ford, I988) en de duur van trainingseffecten (Wexley \& Baldwin, I986). Daarbij kwam naar voren dat trainingen vaak een beperkte effectiviteit bezitten en dat vooral de transfer van het geleerde naar de dagelijkse werksituatie een probleem vormde. De aandacht richtte zich vervolgens op maatregelen voor, tijdens en na de training die de transfer kunnen bevorderen (Broad \& Newstrom, 1992). Daarnaast ontstond door het transferprobleem van externe trainingen belangstelling voor trainingen die op het werk zelf, binnen de dagelijkse werksituatie, plaatsvinden.

Geleidelijk begon men zich te realiseren dat het ontwikkelen van medewerkers op andere manieren kan plaatsvinden dan alleen via formele training en dat de werksituatie zelf een belangrijke bron van leren en ontwikkeling kan zijn. Naast de formele, expliciete, gestructureerde en door experts gestuurde leersituaties kunnen ook informele, impliciete, en minder gestructureerde situaties, met collega's in plaats van experts, leerprocessen in gang zetten. Gebleken is dat dergelijk informeel leren een groter aandeel heeft in het geheel van leerervaringen dan formele, gestructureerde leersituaties (Jacobs \& Jones, I995; Marsick \& Watkins, I99o; McCall, Lombardo \& Morrison, I988). Informele leerervaringen kunnen plaatsvinden tijdens interacties met anderen, zoals bij mentorschap, intercollegiaal overleg, teamwerk, feedback geven of coaching (De Janasz, Sullivan \& Whiting, 2003; Lankau \& Scandura, 2002; Noe et al., I997), of door middel van het werk zelf, bijvoorbeeld door het werken aan uitdagende of nieuwe taken (Holman \& Epitropaki, 20or; McCall et al., I988; McCauley, Ruderman, Ohlott \& Morrow, I994). Functies met een hoge leerwaarde bieden een voedingsbodem voor de verdere uitbouw van expertise en voor het ontwikkelen van professionele kennis en vaardigheden op het huidige functiedomein en op een aangrenzend of nieuw terrein (Boerlijst, Van der Heijden \& Van Assen, I993).

In de literatuur worden verschillende soorten werkgebonden leerervaringen onderscheiden (zie Garrick, I998, voor een overzicht en discussie). Marsick en Watkins (I990) bijvoorbeeld maken een onderscheid tussen informeel en incidenteel leren. 
Bij de eerste vorm, informeel leren, vindt leren intentioneel plaats; de medewerker voert een activiteit uit met de verwachting daarvan te leren, zoals het lezen van een handboek of het vragen om advies. Deze vorm van leren wordt ook wel zelfgestuurd leren genoemd. Bij de tweede vorm, incidenteel leren, vindt leren onbedoeld plaats, zonder een vooropgezette verwachting dat er geleerd zal worden. De leerervaring is dan een bijproduct van andere activiteiten. Als voorbeeld noemen Marsick en Watkins (I990) het leren van ervaringen en fouten, het leren van de acties van anderen en het overnemen van de aannamen of waarden van anderen. Deze strikte scheiding tussen bedoeld en onbedoeld leren is niet altijd mogelijk (denk bijvoorbeeld aan de medewerker die van takenpakket verandert met als doel zich breder te ontwikkelen) en is door anderen dan ook bekritiseerd (Garrick, 1998). Duidelijk is in ieder geval dat er verschillende manieren zijn om tijdens en van de werksituatie te leren, variërend van in het werk geïntegreerd 'onbewust' leren tot op de werkplek ontplooide 'bewuste' leeractiviteiten. Nieuw is deze observatie natuurlijk niet; zij sluit aan op opvattingen over expertiseontwikkeling (Van der Heijden, 20oI) en beroepsgerichte leerprocessen (Eraut, Alderton, Cole \& Senker, I998), en op cognitief interactionele theorieën van leren (zie Dixon, I994; McCauley \& Hezlett, 200I).

\section{Factoren die employability en ontwikkeling kunnen beïnvloeden}

Er zijn verschillende factoren die bepalen of en wat er op het werk wordt geleerd. Aangenomen wordt dat het werk het leren stimuleert wanneer er een discrepantie bestaat tussen de kennis en vaardigheden van de werknemer en de kennis en vaardigheden die voor het werk nodig zijn (Noe et al., I997). In dat geval zal het werk de medewerker uitdagen nieuwe vaardigheden te ontwikkelen of de eigen vaardigheden en kennis op een andere manier te gebruiken (London, I989). Vanuit die gedachte worden veranderingen in de werksituatie, zoals functieroulatie, tijdelijke uitwisselingen en het meewerken aan speciale projecten, gebruikt om de ontwikkeling en employability van de individuele werknemer te bevorderen.

Ook de werksituatie zelf kan tot leren en ontwikkeling aanzetten. Verschillende aspecten kunnen de leerwaarde van de werksituatie vergroten, zoals uitdaging, innovaties, verantwoordelijkheid, feedback en een zekere mate van complexiteit (Lombardo \& Eichenger, I989; McCauley et al., I994; McCauley \& Hezlett, 200I; Noe et al., I997; Poell et al., 2004). Dit laatste aspect, complexiteit, komt terug in de handelingstheorie van Hacker (I998; zie ook Frese \& Zapf, I994). Volgens deze theorie moet een complexe taak als een factor in de ontwikkeling van de persoonlijkheid van een werknemer worden beschouwd, waarbij alleen werknemers die al een complexe taak hebben, bereid zijn taken met een nog grotere complexiteit op zich te nemen (Schyns, 200I). Tot slot is de autonomie binnen een functie van belang. Leren wordt bevorderd wanneer werknemers de mogelijkheid hebben zelf het initiatief te nemen, te experimenteren en te kiezen op welke manier zij een doel willen bereiken (McCall et al., I988; McCauley et al., I994). Sommige functies zijn zo beperkt dat mensen niet in staat worden gesteld om iets te leren dat buiten het directe bereik van hun huidige functie ligt (Boerlijst et al., 1993). 
Naast deze werkkenmerken speelt de sociale werkomgeving een grote rol in leer- en ontwikkelingsprocessen. Collega's zijn belangrijke leveranciers van voorbeelden, feedback en steun (Ashford, Blatt \& VandeWalle, 2003), terwijl mentorschap en intervisiegroepen meer formele manieren zijn om van anderen te leren (Noe et al., I997). Daarnaast kan de leidinggevende het ontwikkelingsproces actief beïnvloeden door de individuele ontwikkeling te steunen of te stimuleren (Birdi, Allen \& Warr, I997; Maurer \& Tarulli, I994; Schyns, 2004; Van Dam, 2003, 2004), bijvoorbeeld door feedback te geven en doelen te stellen (Bezuijen, 2005) of door de mogelijkheid te geven om bepaalde taken uit te voeren (Schyns, 2004). Uit onderzoek komt naar voren dat de ontwikkeling van medewerkers wordt bevorderd door een goede werkrelatie met de leidinggevende zoals dat het geval is bij een hoge LMX-relatie (Basu \& Green, I995; Bezuijen, 2005) en bij transformationeel leiderschap (Basu \& Green, 1997; Bierly, Kessler \& Christensen, 2000).

60 Al de genoemde factoren kunnen worden beschouwd als een onderdeel van de leercultuur van de organisatie. Onderzoek heeft laten zien dat de cultuur van de organisatie een van de belangrijkste factoren is voor het realiseren van werkgerelateerd leren (Newton, Hase \& Ellis, 2002; Pool, 2000). Volgens Seng en collega's is een cultuur waarin leren en het delen van kennis wordt gesteund en gestimuleerd belangrijker voor werkgerelateerd leren dan welke technologische vooruitgang dan ook (Seng, Zannes \& Pace, 2002). Van belang is verder dat de cultuur het maken van fouten toestaat. Organisaties zouden medewerkers de mogelijkheid moeten geven te experimenteren en innovatief gedrag te vertonen. Door een klimaat te creëren waarin medewerkers zich veilig voelen en waarin mogelijkheden bestaan om al doende nieuwe kennis en vaardigheden te verwerven, zal het 'on-the-job' leren en de employablity worden bevorderd. Van Dyck, Frese, Baer en Sonnentag (2005) hebben laten zien dat een dergelijke foutencultuur positieve gevolgen heeft voor de prestaties van een bedrijf

Uiteraard spelen interpersoonlijke verschillen ook een rol bij leerprocessen en -activiteiten. In de eerste plaats is het van belang dat de medewerker gemotiveerd is om te leren (Birdi et al., I997; Noe \& Wilk, I993; Warr \& Bunce, I995), bereid is om de eerder genoemde discrepantie tussen aanwezige en vereiste kwaliteiten te overbruggen (London, 1989) en openstaat voor veranderingen in de werksituatie (Van Dam, 2005). Relevant is tevens het vertrouwen van de werknemer in de eigen capaciteiten (Gist \& Mitchell, 1992), zoals het vermogen om te leren (Birdi et al., I997), te ontwikkelen (Maurer, 200I), met nieuwe en uitdagende situaties om te gaan (Noe et al., 1997) en taken uit te voeren die buiten het bestek van de eigen functie vallen (Parker, I998). De term die deze aspecten omvat is self-efficacy (Bandura, I997). McDonald en Siegall (1992, 1996) hebben bijvoorbeeld laten zien dat self-efficacy positief samenhang met reacties op technologische veranderingen. Medewerkers die meer vertrouwen in zichzelf hadden, pakten veranderingen beter op dan medewerkers met minder zelfvertrouwen. Te weinig zelfvertrouwen kan tot angst en stress leiden (Birdi et al., I997; Maurer, Weiss \& Barbeite, 2003) en daarmee het opnemen van nieuwe informatie belemmeren.

Recentelijk is aandacht geschonken aan de opvattingen, of 'impliciete theorieën' van mensen over de ontwikkelbaarheid van de eigen capaciteiten (Dweck, I986, I999; Kasimatis, Miller \& Marcussen, I996; Maurer, Wrenn, Pierce, Tross \& Collins, 
2003). Dweck (I986) onderscheidt twee impliciete theorieën: de 'incremental theory', die veronderstelt dat een bepaalde capaciteit te ontwikkelen is, en de 'entity theory', die veronderstelt dat een bepaalde capaciteit gegeven en niet te veranderen is. Volgens Dweck (1986, 1999) zullen mensen die van ontwikkeling uitgaan in een prestatiesituatie, zoals het werk, vaker een leerdoeloriëntatie hanteren. Dat wil zeggen dat zij gericht zijn op de eigen ontwikkeling en zich tot doel stellen nieuwe taken onder de knie te krijgen. Onderzoek heeft deze veronderstelling bevestigd. Gebleken is dat mensen die in de ontwikkelbaarheid van capaciteiten geloven inderdaad een leerdoeloriëntatie hanteren. Daarnaast is naar voren gekomen dat mensen met een leerdoeloriëntatie meer geneigd zijn uitdagende taken te kiezen, op een andere - diepere - manier leren, meer feedback zoeken, en bovenal goed presteren (Dweck, I999; Maurer et al., 2003). Dit suggereert dat het geloven in de ontwikkelbaarheid van de eigen capaciteiten en de daarmee samenhangende leerdoeloriëntatie voor het leren op het werk van groot belang zijn. Een leerdoeloriëntatie kan ertoe bijdragen dat een dagelijkse werkstuatie tot een leersituatie wordt en kan daardoor de leerwaarde van de dagelijkse werksituatie versterken.

\section{Individuele ontwikkeling en leeftijd}

Recente demografische ontwikkelingen, i.c. de ontgroening en de vergrijzing van de beroepsbevolking, hebben verstrekkende gevolgen voor de samenstelling van het arbeidsmarktpotentieel. De gemiddelde leeftijd van de beroepsbevolking is vanaf I995 sterk toegenomen en de verwachting is dat deze trend tot ongeveer 2025 alleen maar zal doorzetten. Nu er steeds meer oudere werknemers komen is het van belang aandacht te besteden aan de relatie tussen leeftijd en de individuele ontwikkeling. Ook oudere werknemers moeten ervoor zorgen dat hun competentiebasis continu 'up to date' is. Het is echter de vraag of oudere werknemers wel in staat zijn of voldoende worden gestimuleerd om hun professionele kennis en vaardigheden voortdurend uit te bouwen.

Er zijn aanwijzingen dat oudere werknemers wat betreft de eigen ontwikkeling minder actief zijn. Dat is aangetoond voor zowel trainingen op het werk als door de werkgever betaald leren in de vrije tijd (Warr, 20oI). Ook is gebleken dat de employabilityoriëntatie van werknemers boven de 55 jaar lager is dan die van hun jongere collega's (Van Dam, I998). Mogelijk is sprake van een 'self-fullfilling prophecy', waarbij de oudere medewerker in reactie op de houding van de leidingevende en het daaruit voortkomende tekort aan ontwikkelingsmogelijkheden minder in de eigen ontwikkeling investeert. Onderzoek (Boerlijst et al., I993; Van der Heijden, 2005) heeft namelijk laten zien dat de meeste leidinggevenden in sterke mate instrumenteel leiderschap toepassen. Zij zijn voornamelijk gericht op de toegevoegde waarde van de medewerker in het 'hier-en-nu' en hebben nauwelijks oog voor hun inzetbaarheid op langere termijn. Vooral als hun ondergeschikten wat ouder zijn, blijken leidinggevenden nauwelijks te investeren in activiteiten die de loopbaanontwikkeling en employability van de medewerker bevorderen (Boerlijst et al., I993). Het is mogelijk dat leidinggevenden een inschatting maken van het rendement van een dergelijke investering en het gezien de korte terugverdientijd niet rendabel achten om voor 
ouderen continue expertiseontwikkeling na te streven. Een andere oorzaak kan worden gevonden in de negatieve stereotypen die over oudere werknemers bestaan en die niet alleen betrekking hebben op een vermeende lagere productiviteit, verminderde werkmotivatie en hogere kosten, maar ook op hun ongeschiktheid voor leeractiviteiten (Solomon, 1995). Hoewel de meeste van deze stereotypen in onderzoek zijn ontkracht (zie Solomon, I995), geven oudere werknemers in sommige gevallen zelf aan dat zij zichzelf te oud vinden om te leren (Warr, 20or). Dit laat zien dat het van belang is aandacht te schenken aan de ontwikkelingsmotivatie van oudere werknemers en voldoende ontwikkelingsmogelijkheden te bieden om te voorkomen dat zij stagneren in hun ontwikkeling en voortijdig moeten worden 'afgeschreven'. De ontwikkeling kan ook in gevaar komen door een leeftijdsgerelateerde achteruitgang in de cognitieve vermogens. Naarmate mensen ouder worden, nemen verschillende cognitieve functies zoals selectieve aandacht en het werkgeheugen af, 62 waardoor het verwerken van nieuwe informatie moeilijker wordt (Salthouse, I996). Met name het vermogen nieuwe dingen (losse feiten) te leren neemt af. Deze effecten zijn tot het zestigste jaar niet dramatisch, maar daarna wordt dit vermogen duidelijker minder (Warr, 200I). Deze achteruitgang is vooral waarneembaar bij complexe taken die behoorlijke eisen aan de persoon stellen; bij eenvoudige taken zijn de leeftijdsverschillen in cognitief functioneren kleiner of afwezig (Craik \& Jacoby, I996). Overigens geldt dat de verschillen in cognitieve vermogens tussen ouderen veel groter zijn dan de verschillen tussen jongeren, wat aangeeft dat sommige ouderen veel minder last hebben van een cognitieve achtergang dan hun leeftijdsgenoten.

Doordat de verwerking van informatie achteruitgaat, kunnen sommige oudere werknemers meer moeite met leren hebben. Van trainingen met een vaste tijdsduur zullen oudere werknemers gemiddeld minder opsteken dan jongere werknemers (Warr, Allan \& Birdi, I999). Krijgen zij meer tijd, dan kunnen zij nagenoeg hetzelfde leerresultaat behalen als jongeren. De leerprestatie verbetert ook als het materiaal sterk refereert aan eerder opgebouwde expertise. Wil een werksituatie ook voor oudere medewerkers een leerwaarde hebben, dan is het raadzaam om de situatie te laten aansluiten op eerdere werksituaties en de daar ontwikkelde kennis en vaardigheden en de medewerker iets meer tijd te geven zich de nieuwe situatie eigen te maken.

Opgemerkt moet worden dat deze achteruitgang in cognitieve vermogens over het algemeen geen invloed heeft op de werkprestaties van ouderen (Warr, 200I). De prestaties lijken eerder toe te nemen met leeftijd of in ieder geval stabiel te zijn. In veel banen zijn deze cognitieve vermogens namelijk niet allesbepalend. Daar leveren domeinspecifieke kennis en verworven cognitieve strategieën een belangrijke bijdrage aan prestaties. Ouderen presteren beter omdat hun jarenlange ervaring tot meer inzicht, impliciete kennis en kennis over procedures heeft geleid. Deze ervaringscomponent zorgt ervoor dat het probleemoplossende vermogen van ouderen vaak beter is dan dat van jongeren; zij hebben meer inzicht, herkennen sneller de aard van het probleem en weten beter welke strategieën effectief zijn. Wel is dit vermogen domeinspecifiek; vooral binnen dit domein zullen ouderen beter presteren dan jongeren. Organisaties moeten zich daarom realiseren dat het overplaatsen van oudere werknemers naar nieuwe domeinen of de blootstelling aan de snelle ver- 
anderingen die tegenwoordig in het werk plaatsvinden dit op ervaring gebaseerde vermogen kan ondermijnen.

\section{Besluit}

In dit artikel is aandacht besteed aan conceptualisaties van en onderzoek naar employability en individuele ontwikkeling in professionele settings. Werkgerelateerd leren en ontwikkelen vormen de kern van het hedendaagse HRD (Sambrook, 2005) en moeten worden geplaatst binnen de context van de hedendaagse ontwikkelingen op de arbeidsmarkt, de internationalisering, individualisering, informatisering en intensificatie van de maatschappij (zie ook Schnabel, 200o). Life-long employability vraagt veel van mensen en het is urgent om gezamenlijk de verantwoordelijkheid te dragen voor het optimaliseren van het arbeidsmarktpotentieel. Dat betreft werknemers en werkgevers. Werknemers kunnen een bijdrage leveren door zich open te stellen voor veranderingen en (pro)actief aan de eigen competentieontwikkeling te werken. Werkgevers kunnen een bijdrage leveren door faciliteiten te bieden, een stimulerende rol te spelen en de mogelijkheden en beperkingen van verschillende categorieën personeel in het oog te houden.

Er is ook een belangrijke rol voor onderzoekers weggelegd: onderzoek naar employability en individuele ontwikkeling zou ons inziens binnen een non-normatief raamwerk moeten plaatsvinden. Omdat dit onderzoek voornamelijk in westerse culturen is uitgevoerd, spelen westerse aannamen ten aanzien van ontwikkeling bewust of onbewust een rol (McCauley \& Hezlett, 200I). Zo wordt er vaak impliciet van uitgegaan dat werk een centrale plaats in het leven inneemt, ontwikkeling primair een persoonlijk fenomeen is, persoonlijke ontwikkeling wenselijk is, de meeste mensen zich kunnen ontwikkelen, en het openstaan voor veranderingen goed is (Hoppe, 1998). Het zal niet moeilijk zijn deze aannamen ook in dit artikel te herkennen. Daarnaast bestaat er een relatie tussen de manier waarop naar individuele ontwikkeling wordt gekeken en opvattingen over loopbaanontwikkeling en loopbaansucces. Het is echter de vraag of deze aannamen en opvattingen voor alle mensen van toepassing zijn. Onderzoekers zouden meer rekening kunnen houden met de pluriformiteit van de beroepsbevolking. Mensen hebben verschillende opvattingen over loopbaansucces, hebben verschillende behoeftes en affiniteiten, en denken verschillend over de wijze waarop zij hun professionele leven invulling willen geven, en dat terwijl de wereld voortdurend verandert. Het zou raadzaam zijn als onderzoekers bij het bestuderen van de factoren die samenhangen met groei en employability een perspectief hanteren waarin ruimte is voor individuele verschillen en wensen, en waarin modellen worden ontwikkeld die voortdurend worden geëvalueerd in het licht van cohorteffecten, maatschappelijke veranderingen en demografische ontwikkelingen. Daarnaast zou het nuttig zijn meer inzicht te krijgen in de invloed van de uitwisselingsrelatie tussen de werknemer en de organisatie op de individuele ontwikkeling en employability van de werknemer. Het is niet ondenkbaar dat juist in tijden van grote onzekerheden, hoge verwachtingspatronen en een continue druk om zich blijvend te ontwikkelen, de behoefte aan een vruchtbare en betrouwbare uitwisselingsrelatie alleen maar groter wordt. 


\section{Literatuur}

Arthur, M.B. (1994). The boundaryless career: A new perspective for organizational inquiry. Journal of Organizational Behavior, 15, 295-306.

Ashford, S.J., Blatt, R. \& VandeWalle, D. (2003). Reflections on the looking glass: A review of research on feedback-seeking behavior in organizations. Journal of Management, 29, 773-799.

Ashford, S.J. \& Taylor, M.S. (1990). Adaptation to work transitions: An integrative approach. In G.R. Ferris \& K.M. Rowland (Red.), Research in personnel and human resources management (Vol. 8, pp. I-39). Greenwich, CT: JAI Press.

Atkinson, J. (1984). Manpower strategies for flexible organizations. Personnel Management, I6, 28-3I.

Baldwin, T.T. \& Ford, J.K. (1988). Transfer of training: A review and directions for future research. Personnel Psychology, 4I, 63-105.

Bandura, A. (1997). Self-efficacy: The exercise of control. New York, NY: Freeman.

Basu, R. \& Green, S.G. (1995). Subordinate performance, leader-subordinate compatibility, and exchange quality in leader-member dyads: A field study. Journal of Applied Social Psychology, 25, 77-92.

Basu, R. \& Green, S.G. (1997). Leader-member exchange and transformational leadership: An empirical examination of innovative behaviors in leader-member dyads. Journal of Applied Social Psychology, 27, 477-499.

Bettencourt, L.A. (2004). Change-oriented organizational citizenship behaviors: The direct and moderating influence of goal orientation. Journal of Retailing, 80, 165-180.

Bezuijen, X.M. (2005). Leadership and employee development. Academisch proefschrift, Universiteit van Tilburg.

Bierly, P.E., Kessler, E.H. \& Christensen, E.W. (2000). Organizational learning, knowledge, and wisdom. Journal of Organizational Change Management, 13, 595-618.

Birdi, K., Allan, C. \& Warr, P. (1997). Correlates and perceived outcomes of 4 types of employee development activity. Journal of Applied Psychology, 82, 845-857.

Boerlijst, J.G., Heijden, B.I.J.M. van der \& Assen, A. van (1993). Veertig-plussers in de onderneming. Assen: Van Gorcum/Stichting Management Studies.

Broad, M.L. \& Newstrom, J.W. (1992). Transfer of training: Action-packed strategies to ensure high pay-off from training investments. San Francisco: Addison-Wesley.

Burns, T. \& Stalker, G.M. (I966). The management of innovation. Welwyn Garden City: Tavistock Publications Ltd.

Chan, D. (2000). Understanding adaptation to changes in the work environment: Integrating individual difference and learning perspectives. In G.R. Ferris (Red.), Research in personnel and human resources management (Vol. I8, pp. I-42). Stanford, CT: JAI Press.

Craik, F.I.M. \& Jacoby, L.L. (1996). Aging and memory: Implications for skilled performance. In W.A. Rogers, A.D. Fiske \& N. Walker (Red.), Aging and skilled performance (pp. II3-I37). Mahwah, NJ: Erlbaum.

Crant, J.M. (2000). Proactive behavior in organizations. Journal of Management, 26, 435-462.

Dam, K. van (1998). Employability, een consequentie van de flexibele organisatie. De Psycholoog, 33, 254-259.

Dam, K. van (2003). Understanding experts' attitudes toward functional flexibility. International Journal of Human Resources Development and Management, 3, I38-154.

Dam, K. van (2004). Antecedents and consequences of employability orientation. European Journal of Work and Organizational Psychology, I3, 29-5I.

Dam, K. van (2005). Employee attitudes toward job changes: An application and extension of Rusbult and Farrell's investment model. Journal of Occupational and Organizational Psychology, 78, 253-272.

Dixon, N.M. (I994). The organizational learning cycle: How we can learn collectively. London: McGraw-Hill.

Dweck, C.S. (1986). Motivational processes affecting learning. American Psychologist, $4 \mathrm{I}$, IO4O-IO48. 
Dweck, C.S. (1999). Self-theories: Their role in motivation, personality, and development. Philadelphia, PH: Psychology Press.

Dyck, C. van, Frese, M., Baer, M. \& Sonnentag, S. (2005). Organizational error management culture and its impact on performance: A two-study replication. Journal of Applied Psychology, 90, г228-г240.

Eraut, M., Alderton, J., Cole, G. \& Senker, P. (1998). Development of knowledge and skills in employment. Research report 5. Brighton: University of Sussex Institute of Education.

Feintuch, A. (1955). Improving the employability and attitudes of 'difficult to place persons'. Psychological Monographs, 69, 392-397.

Forrier, A. \& Sels, L. (2003). The concept employability: A complex mosaic. International Journal of Human Resources Development and Management, 3, Ioo-I24.

Frese, M. \& Fay, D. (20or). Personal initiative: An active performance concept for work in the 2Ist century. In B.M. Staw \& R.I. Sutton (Red.), Research in organizational behavior (Vol. 23, pp. 133-187). Amsterdam: Elsevier.

Frese, M. \& Zapf, D. (1994). Action as the core of work psychology: A German approach. In H.C. Triandis, M.D. Dunette \& L.M. Hough (Red.), Handbook of industrial and organizational psychology (4 ${ }^{\text {th }}$ ed, pp. 271-340). Palo Alto: Consulting Psychologists Press.

Fugate, M., Kinicki, A.J. \& Ashforth, B.E. (2004). Employability: A psycho-social construct, its dimensions, and applications. Journal of Vocational Behavior, 65, 14-38.

Garrick, J. (1998). Informal learning in the workplace; Unmasking human resource development. London: Routledge.

Gaspersz, J. \& Ott, M. (1996). Management van employability. Assen: Van Gorcum.

Gazier, B. (1998). Employability: Definitions and trends. In B. Gazier (Red.), Employability: Concepts and policies. Berlin: European Employment Observatory.

Gist, M. \& Mitchell, T. (I992). Self-efficacy: A theoretical analysis of its determinants and malleability. Academy of Management Review, I7, I83-2II.

Glasbergen, M.P. (1994). Flexibele en blijvende inzetbaarheid van machinebedieners in de grafische industrie. Academisch proefschrift, Universieit Twente.

Glastra, F.J., Van der Haar, S., Lens, M.E. \& Schedler, P.E. (2004). Tussen flexibiliteit en samenhang. In F.J. Glastra, S. van der Haar, M.E. Lens \& P.E. Schedler (Red.), Losse koppelingen: Over flexibilisering van arbeid, organisatie en leefwereld (pp. 13-48). 's Gravenhagen: Reed Business Information.

Grip, A. de, Loo, J. van \& Sanders, J. (2004). The industry employability index: Taking account of supply and demand characteristics. International Labour Review, I43, $2 \mathrm{II}-233$.

Guest, D.E. (1987). Human resource management and industrial relations. Journal of Management Studies, 24, 503-52I.

Hacker, W. (1998). Allgemeine Arbeitspsychologie: Psychische Regulation von Arbeitstätigkeiten. Bern: Hans Huber.

Hall, D.T. (1976). Careers in organizations. Gleniew, IL: Scott, Foreman.

Hall, D.T. (2002). Careers in and out of organizations. Thousand Oaks, CA: Sage.

Handy, C. (1988). Understanding voluntary organizations. London: Penguin.

Harvey, L. (200I). Defining and measuring employability. Quality in Higher Education, 7, 97-IO9.

Heijden, B.I.J.M. van der (200I). Encouraging professional development in small and medium-sized firms: The influence of career history and job content. Career Development International, 6, I56-168.

Heijden, B.I.J.M. van der (2005). No one has ever promised you a rose garden; On shared responsibility and employability enhancing strategies throughout careers. Inaugurale rede, Open Universiteit Heerlen. Assen: Van Gorcum.

Heijden, B.I.J.M. van der \& Thijssen, J.G.L. (2003). Editorial: HRD and employability. International Journal of Human Resources Development and Management, 3, 99-IOI.

Hillage, J. \& Pollard, E. (1998). Employability: Developing a framework for policy analysis. London: DfEE.

Holman, D. \& Epitropaki, O. (200I). Understanding learning strategies in the workplace: A factor analytic investigation. Journal of Occupational and Organizational Psychology, 74, 675-68r. 
Hoppe, M.H. (1998). Cross-cultural issues in leadership development. In C.D. McCauley, R.S. Moxley \& E. van Velsor (Red.), The Center of Creative Leadership handbook of leadership development (pp. 336-378). San Francisco: Jossey-Bass.

Jacobs, R.L. \& Jones, M.J. (I995). Structured on-the-job training: Unleashing employee expertise in the workplace. San Francisco: Berrett-Koehler.

Janasz, S.C. de, Sullivan, S.E. \& Whiting, V. (2003). Mentor networks and career success: Lessons for turbulent times. Academy of Management Executive, I7, 78-9I.

Kasimatis, M., Miller, M. \& Marcussen, L. (1996). The effects of implicit theories on exercise motivation. Journal of Research in Personality, 30, 510-516.

Kluytmans, F. \& Ott, M. (I999). Management of employability in the Netherlands. European Journal of Work and Organizational Psychology, 8, 26I-272.

Lankau, M.J. \& Scandura, T.A. (2002). An investigation of personal learning in mentoring relationships: Content, antecedents, and consequences. Academy of Management Journal, $45,779^{-7} 790$.

Legge, K. (I995). Human resource management; Rhetorics and realities. Basingstoke: MacMillan.

Lombardo, M.M. \& Eichenger, R.W. (1989). Eighty eight assignments for development in place: Enhancing the developmental challenge of existing jobs. Greensboro, NC: Center for Creative Leadership.

London, M. (1989). Managing the training enterprise. San Francisco: Jossey-Bass.

London, M. \& Mone, E.M. (1999). Continuous learning. In D.R. Ilgen \& E.D. Pulakos (Red.), The changing nature of performance (pp. II9-153). San Francisco: Jossey-Bass.

Marsick, V. \& Watkins, K.E. (1990). Informal and incidental learning in the workplace. London: Routledge.

Maurer, T.J. (200I). Career-relevant learning and development, worker age, and beliefs about self-efficacy for development. Journal of Management, 27, I23-I4O.

Maurer, T.J. \& Tarulli, B.A. (I994). Investigation of perceived environment, perceived outcome, and person variables in relationship to voluntary development activities by employees. Journal of Applied Psychology, 79, 544-560.

Maurer, T.J., Weiss, E.M. \& Barbeite, F.G. (2003). A model of involvement in work-related learning and development activity: The effects of individual, situational, motivational, and age variables. Journal of Applied Psychology, 88, 707-724.

Maurer, T.J., Wrenn, K.A., Pierce, H.R., Tross, S.A. \& Collins, W.C. (2003). Beliefs about 'improvability' of career-relevant skills: Relevance of job/task analysis, competency modeling, and learning orientation. Journal of Organizational Behavior, 24, IO7-I3I.

McCall, M.W., Lombardo, M.M. \& Morrison, A.M. (1988). The lessons of experience. Lexington, MA: Lexington Books.

McCauley, C.D. \& Hezlett, S.A. (200I). Individual development in the workplace. In N. Anderson, D.S. Ones, H.K. Sinangil \& C. Viswesvaran (Red.), Handbook of work and organizational psychology: Vol. r. Personnel psychology (pp. 313-335). London: Sage.

McCauley, C.D., Ruderman, M.N., Ohlott, P.J. \& Morrow, J.E. (1994). Assessing the developmental components of managerial jobs. Journal of Applied Psychology, 79, 544-560.

McDonald, T. \& Siegall, M. (I992). The effects of technological self-efficacy and job focus on job performance, attitudes, and withdrawal behaviors. Journal of Psychology, I26, $465-475$.

McDonald, T. \& Siegall, M. (1996). Enhancing worker self-efficacy: An approach for reducing negative reactions to technological change. Journal of Managerial Psychology, II, 4I-44.

McQuaid, R.W. \& Lindsay, C. (2005). The concept of employability. Urban Studies, 42, I97-219.

McQuaid, R.W., Green, A. \& Danson, M. (2005). Introducing employability. Urban Studies, 42, I9I-I95.

Newton, D., Hase, S. \& Ellis, A. (2002). Effective implementation of online learning: A case study of the Queenland mining industry. Journal of Workplace Learning, I4, I56-165.

Noe, R.A. \& Wilk, S.L. (1993). Investigation of the factors that influence employees' participation in development activities. Journal of Applied Psychology, 78, 29I-302. 
Noe, R.A., Wilk, S.L., Mullen, E.J. \& Wanek, J.E. (1997). Employee development: Issues in construct definition and investigation of antecedents. In J.K. Ford, S. Kozlowski, K. Kraiger \& M. Teachout (Red.), Improving training effectiveness in work organizations (pp. I53-188). Hillsdale, NJ: Erlbaum.

Parker, S.K. (1998). Enhancing role-breath self-efficacy: The roles of job enrichment and other organizational interventions. Journal of Applied Psychology, 83, 835-852.

Poell, R.F., Dam, K. van \& Berg, P.T. van den (2004). Organising learning in work contexts. Applied Psychology: An International Review, 53, 529-540.

Pool, S.W. (2000). The learning organization: Motivating employees by integrating TQM philosophy in a supportive organizational culture. Leadership \& Organizational Development Journal, 2I, 373-378.

Pulakos, E.D., Arad, S., Donovan, M.A. \& Plamondo, K.E. (2000). Adaptability in the workplace: Development of a taxonomy of adaptive performance. Journal of Applied Psychology, 85, 612-624.

Robinson, D.G. \& Robinson, J.C. (1989). Training for impact. San Francisco: Jossey-Bass.

Salthouse, T.A. (1996). The processing-speed theory of adult age differences in cognition. Psychologial Review, I03, 403-428.

Sambrook, S. (2005). Factors influencing the context and process of work-related learning: Synthesizing findings from two research projects. Human Resource Development International, 8, IOI-II9.

Schnabel, P. (2000). Maatschappij in beweging. In: Herijken achter de dijken, verslag van het jubilieumcongres van de Sociaal-Economische Raad, in Oktober 2000. Den Haag: SociaalEconomische Raad.

Schyns, B. (200I). Determinanten beruflicher Veränderungsbereitschaft bei Arbeitnehmern und Arbeitnehmerinnen unterer Hierarchieebenen. Academisch proefschrift, Universität Leipzig.

Schyns, B. (2004). The influence of occupational self-efficacy on the relationship of leadership behavior and preparedness for occupational change. Journal of Career Development, 30, 247-261.

Seng, C.V., Zannes, E. \& Pace, R.W. (2002). The contribution of knowledge management to workplace learning. Journal of Workplace Learning, I4, I38-I47.

Solomon, C.M. (1995). Unlock the potential of older workers. Personnel Journal, 74, 56-66.

Steenbakkers, A.I.R. (I996). Stimuleren van flexibiliteit. Een onderzoek naar condities van beroepsmatige flexibiliteit van werknemers. Gedrag E Organisatie, 9, II5-130.

Thijssen, J.G.L. (2000). Employability in het brandpunt. Aanzet tot verheldering van een diffuus concept. Tijdschrift voor HRM, 3, 7-37.

Warr, P. (200I). Age and work behaviour: Physical attributes, cognitive abilities, knowledge, personality traits and motives. International Review of Industrial and Organizational Psychology, $16, \mathrm{I}-36$.

Warr, P.B., Allan, C. \& Birdi, K. (1999). Predicting three levels of training outcomes. Journal of Occupational and Organizational Psychology, 72, 351-375.

Warr, P.B. \& Bunce, D.J. (1995). Trainee characteristics and the outcomes of open learning. Personnel Psychology, 48, 347-375.

Wexley, K.N. \& Baldwin, T.T. (1986). Post-training strategies for facilitating positive transfer: An empirical exploration. Academy of Management Journal, 29, 503-520.

\section{Summary}

\section{Employability and employee development at work}

Karen van Dam, Beatrice I.J.M. van der Heijden en Birgit Schyns, Gedrag $\&$ Organisatie, Volume 19, Maart 2006, nr. 1, pp. 53-68

In the past decades, employability and employee development have received increased attention. Changes within and around organizations have emphasized the need for flexible firms and a multi-skilled work force, while, at the same time, 
employees have become responsible for their own careers and work security. The present article first reviews recent changes underlying the need for employability and employee development. Subsequently, attention is paid to the concepts of employability and workplace learning, factors affecting learning at work, and agerelated influences. With this article, we aim to kick off a new series for Gedrag $\mathcal{E}$ Organisatie on employee development and employability in organizations.

Key words: employee development, employability, workplace learning, HRD 